\title{
ALTERNATIF PEMBIAYAAN LEASING DAN DEBT FINANCING AKTIVA TETAP PADA UD. RIKY S.Y DI DESA GONTORAN KECAMATAN LINGSAR KABUPATEN LOMBOK BARAT
}

\author{
I GUSTI AGUNG DIDIT EKA PERMADI
}

\author{
Fakultas Pertanian UNMAS Mataran
}

ABSTRAK

e-mail : diditekapermadi@gmail.com

Sejak tahun 2013 perkembangan aktivitas budidaya perikanan yang dilakukan oleh UD. Riky S.Y terus mengalami peningkatan dan perusahaan berencana untuk melakukan perluasan usaha, maka daripada itu perusahaan membutuhkan sejumlah aktiva tetap berupa kolam pemeliharaan ikan dan kendaraan (mobil pick up). Untuk mengatasi permasalahan tersebut ada dua alternatif pembiayaan perolehan aktiva tetap yang bisa diterapkan. Alternatif pertama adalah dengan caraleasing dan alternatif kedua adalah dengan cara debt financing. Jenis penelitian yang digunakan adalah penelitian terapan dengan metode studi kasus.Data diperoleh dengan menggunakan teknik pengumpulan data yaitu observasi, wawancara, dan dokumentasi. Untuk menjawab pertanyaan penelitian yang diajukan digunakan analisis present value, dengan kriteria pilihan yaitu yang mempunyai present value aliran kas pembiayaan yang lebih kecil. Dari hasil analisa dan pembahasan diperoleh bahwa present value aliran kas keluar untuk kolam pemeliharaan ikan dengan ukuran 16 x 6 meter dengan alternatif leasing periode 2013/2014-2017/2018 adalah sebesar Rp 48.278.250,-. Sedangkan untuk alternatif debt financing pada periode yang sama adalah sebesar Rp 66.530.066,-. Present value aliran kas keluar untuk kendaraan (mobil pick up) dengan alternatif leasing periode yang sama adalah sebesar Rp 398.823.300,- dan untuk alternatif debt financing adalah sebesar Rp 222.446.799,-. Dapat disarankan kepada UD.Riky S.Y untuk menggunakan alternatif leasing dan alternatif debt financing dalam memperoleh aktiva tetapnya.

Kata kunci :leasing, debt financing, aktiva tetap, present value, aliran kas.

\section{ABSTRACT}

The progress activity of aquaculture which conducted by UD. Riky S.Y have got the increase since 2008, so that the company make plan to expand their bussiness, they need a number of fixed asset such as pool of pisciculture and car, to overcome the problem there are two alternatives of aquasition financing fixed asset is applied. First alternative applied is leasing and for to second alternatives by using debt financing, kind of this research is applied research by case study method, and data received by applying data collecting tehknique, namely observation, interview, and documentation, to answer the question proposed in this research is analysis of present value, by criteria choice that is present value which has the smaller financing. From analysis data and discussion received that present value of spent cash flow for pool pisciculture by measuring is $16 \times 6 \mathrm{~m}$ with leasing alternative of period for 2013/2014 - 2017/2018 is about $R p$ 48.278.250 while for debt financing alternative for the same period is about $R p$ 66.530.066, spent cash flow for car by leasing alternative for the same period is about Rp398.823.300, and for debt financing alternative is about $R p 222.446 .799$ and can be recommended to UD. Riky S.Y to apply the leasing alternative and debt financing alternative in receiving the fixed asset.

Key words : leasing, debt financing, fixed asset, present value, and cash flow. 


\section{PENDAHULUAN}

\section{Latar Belakang}

Setiap perusahaan, baik yang bergerak di bidang manufaktur maupun jasa, pada umumnya selalu mengharapkan dapat mempertahankan kelangsungan hidup perusahaannya, serta tumbuh berkembang ke arah yang lebih maju.Dalam mewujudkan keadaan tersebut perusahaan dihadapkan pada berbagai kendala, seperti masalah persaingan, permodalan, fasilitas yang ada, dan sumber daya yang tersedia.Oleh karena itu pihak perusahaan harus mampu mengelola, mengkoordinir, dan mengawasi semua kegiatan pokok perusahaan, seperti personalia, produksi, pemasaran, keuangan, dan kegiatan operasional lainnya yang ada dalam suatu perusahaan. Kegiatan-kegiatan tersebut akan saling menunjang satu sama lainnya, hal ini berarti pengambilan keputusan pada salah satu kegiatan perusahaan akan membawa pengaruh pada kegiatankegiatan lainnya. Untuk itu dibutuhkan kemampuan pimpinan perusahaan dalam mengorganisir serta mengawasi kegiatan-kegiatan operasional tersebut guna diarahkan pada pencapaian tujuan yang telah ditetapkan.

Salah satu yang mempunyai peranan penting adalah bagian pembelanjaan (keuangan), karena kegiatan pembelanjaan tidak dapat dipisahkan dari kegiatan operasional perusahaan. Apabila kegiatan pembelanjaan kurang memadai maka kegiatan usaha akan tersendat dan akhirnya tujuan perusahaan sulit dicapai.

Kegiatan pembelanjaan pada pokoknya menyangkut masalah pengalokasian sumber dana yang dimiliki oleh perusahaan dan bagaimana perusahaan berusaha untuk menyediakan dana yang dibutuhkan. Menurut Sutrisno (2003:3), "Manajemen keuangan atau sering disebut pembelanjaan dapat diartikan sebagai semua aktivitas perusahaan yang berhubungan dengan usaha-usaha mendapatkan dana perusahaan dengan biaya yang murah serta usaha untuk menggunakan dan mengalokasikan dana tersebut secara efisien”. Dari pengertian tersebut maka pembelanjaan meliputi dua hal yaitu berhubungan dengan masalah mendapatkan dana untuk keperluan perusahaan dan berhubungan dengan pengalokasian dana yang telah diperoleh.

UD. Riky S.Y adalah perusahaan yang bergerak di bidang usaha budidaya perikanan yang kegiatan utamanya adalah membudidayakan ikan air tawar (ikan nila) untuk memenuhi konsumsi bagi masyarakat di Pulau Lombok. Perusahaan ini didirikan pada tahun 2005 di mana perusahaan ini hanya menjual ikan nila sebagai produk utamanya.UD.Riky S.Y beralamat di Jalan Baru Mekar Dusun Keroya Desa Gontoran Kecamatan Lingsar Kabupaten Lombok Barat.

Sejak tahun 2013 perkembangan aktivitas budidaya perikanan yang dilakukan oleh UD.Riky S.Y terus mengalami peningkatan dan perusahaan berencana untuk melakukan perluasan usaha, maka daripada itu perusahaan membutuhkan sejumlah aktiva tetap berupa tanah, kolam pemeliharaan ikan, mesin pompa air, dan kendaraan.Karena volume permintaan pasar terhadap ikan nila selalu melebihi volume produksi dan volume penjualan yang ada maka terjadi kelebihan volume permintaan pasar, sehingga untuk mengatasi kelebihan volume permintaan pasar inilah perusahaan berusaha meningkatkan kapasitas produksinya.

Kapasitas produksi ikan nila bisa ditingkatkan dengan cara menambah jumlah aktiva tetap yang dimiliki oleh perusahaan berupa kolam pemeliharaan ikan. Di samping itu karena lokasi aktivitas pembudidayaan yang menyebar diantaranya berada di Dusun Keroya Desa Gontoran, Dusun Repok Pancor Desa Sigrongan, dan Butun Kelurahan Sweta Kota Mataram maka diperlukan penambahan armada kendaraan berupa mobil pick up sebagai alat angkut dalam kegiatan operasional aktivitas pembudidayaan, sehingga bertitik tolak dari kedua permasalahan tersebut perusahaan perlu melakukan penambahan jumlah aktiva tetap.

Dalam menjalankan usahanya, UD. Riky S.Y selain menggunakan aktiva tetap yang dimiliki sendiri juga menggunakan tambahan aktiva tetap yang diperoleh dengan cara sewa guna usaha (leasing) dari perusahaan yang menyewakan aktiva tetapnya. Sewa guna usaha (leasing) dilakukan karena terbatasnya aktiva tetap yang tersedia dalam perusahaan sehingga tidak cukup untuk mendukung aktivitas pembudidayaan sampai panen ikan.Di mana aktivitas tersebut harus dilaksanakan berdasarkan jadwal masa pembibitan, pemeliharaan, dan panen yang telah ditetapkan. Apabila perusahaan tidak dapat mengantisipasi permasalahan tersebut, dikhawatirkan akan terjadi keterlambatan dalam masa panen ikan nantinya, sehingga perusahaan akan mengalami kerugian.

Adapun langkah yang diambil oleh perusahaan untuk menghindari kerugian tersebut adalah dengan melakukan sewa guna usaha (leasing) aktiva tetap dari pihak luar.Sewa guna usaha (leasing) dilakukan untuk menambah jumlah aktiva tetap yang digunakan, di mana aktiva tetap yang dimiliki sekarang jumlahnya terbatas. 
Dalam penelitian ini penulis mencoba untuk menerapkan alternatif lain pada UD. Riky S.Y, dari cara perolehan yang dilakukan dengan meyewa (leasing) menjadi alternatif membeli aktiva tetap tersebut yang dibelanjai dari sumber dana hutang (debt financing). Dari kedua alternatif tersebut yang nantinya akan dipilih adalah yang memberikan kriteria biaya atau pengorbanan biaya yang lebih kecil.

Jenis aktiva tetap yang disewa oleh UD. Riky S.Y, khususnya untuk kontrak sewa (leasing) keuangan adalah satu unit kolam pemeliharaan ikan dengan ukuran 16 × 6 meter dan satu unit kendaraan (mobil pick up). Pada tabel-tabel berikut ini dapat dilihat besarnya biaya sewa untuk satu unit kolam pemeliharaan ikan dengan ukuran 16 x 6 meter periode 2013/2014-2017/2018 dan satu unit kendaraan (mobil pick up) periode 2013/2014-2017/2018.

Tabel 1. Biaya Sewa Satu Unit Kolam Pemeliharaan Ikan dengan Ukuran 16 x 6 meter oleh UD. Riky S.Y periode 2013/2014-2017/2018.

\begin{tabular}{|c|c|}
\hline Tahun & Pembayaran Sewa (Rp) \\
\hline 0 & 1.300 .000 \\
\hline $2013 / 2014$ & 1.300 .000 \\
\hline $2014 / 2015$ & 1.300 .000 \\
\hline $2015 / 2016$ & 1.300 .000 \\
\hline $2016 / 2017$ & 1.300 .000 \\
\hline $2017 / 2018$ & - \\
\hline
\end{tabular}

Sumber : UD. Riky S.Y, 2018.

Tabel 2.Biaya Sewa Satu Unit Kendaraan (Mobil Pick Up) oleh UD.Riky S.Y periode 2013/2014-2017/2018.

\begin{tabular}{|c|c|}
\hline Tahun & Pembayaran Sewa (Rp) \\
\hline 0 & 108.000 .000 \\
\hline $2013 / 2014$ & 108.000 .000 \\
\hline $2014 / 2015$ & 108.000 .000 \\
\hline $2015 / 2016$ & 108.000 .000 \\
\hline $2016 / 2017$ & 108.000 .000 \\
\hline $2017 / 2018$ & - \\
\hline
\end{tabular}

Sumber : UD. Riky S.Y, 2018.

Dari Tabel 1 dan Tabel 2 di atas terlihat bahwa biaya sewa untuk satu unit kolam pemeliharaan ikan dengan ukuran 16 x 6 meter adalah sebesar Rp 1.300.000,-/tahun dan untuk satu unit kendaraan (mobil pick up) adalah sebesar Rp 108.000.000,-/tahun.

Aktiva tetap berupa satu unit kolam pemeliharaan ikan dengan ukuran 16 x 6 meter dan satu unit kendaraan (mobil pick up) disewa dari Perusahaan UD. Sari Nila yang merupakan pihak pemilik aktiva tetap (lessor) dan sekaligus sebagai rekan (partner) bisnis dari Perusahaan UD.Riky S.Y. Pembayaran sewa aktiva tetap tersebut dilakukan secara tahunan. Pihak kreditur atau lender yang berperan dalam hal memberikan kredit atau penyediaan dana untuk membeli aktiva tetap bagi pihak lessor adalah Bank Rakyat Indonesia (BRI) Cabang Mataram. Khusus untuk kendaraan (mobil pick up) merkIsuzuPanther, pihak lessor membelinya dari Perusahaan Brawijaya Motor dan perusahaan ini sekaligus berperan sebagai pihak supplier.

Besarnya pembayaran sewa serta ketentuan lainnya yang berhubungan dengan ketentuan sewa guna usaha, diatur dalam suatu perjanjian kontrak sewa (lease agreement) di antara kedua belah pihak.Biaya sewa yang telah ditetapkan harus dibayar secara periodik selama periode sewa.Pada akhir masa kontrak sewa UD.Riky S.Y mempunyai hak untuk memperpanjang sewa untuk periode berikutnya atau membeli aktiva tetap tersebut.

Sedangkan besarnya harga perolehan untuk satu unit kolam pemeliharaan ikan dengan ukuran 16 x 6 meter adalah sebesar Rp 40.000.000,- dan satu unit kendaraan (mobil pick up) adalah sebesar Rp 190.000.000,-. Tingkat bunga kredit bank yang berlaku adalah 13\% yang diperoleh dari Kredit Usaha Rakyat (KUR) Ritel Bank Rakyat Indonesia (BRI) yang diakses dari situs http://komite-kur.com/bank_bri.asp pada hari Jumat tanggal 11 Oktober 2013 pukul 12.58 Wita.

\section{Perumusan Masalah}

Dari uraian di atas, maka dapat dirumuskan permasalahan adalah sebagai berikut : "Alternatif pembiayaan manakah yang paling menguntungkan bagi UD.Riky S.Y dalam pengambilan keputusan 
penyediaan aktiva tetapnya, melalui alternatif pembiayaan leasing atau dengan alternatif pembiayaan debt financing".

\section{Tujuan Penelitian}

Tujuan dari penelitian ini adalah untuk menganalisis besarnya biaya yang dikeluarkan oleh UD.Riky S.Y dalam menggunakan aktiva tetap, baik melalui alternatif pembiayaan leasing maupun debt financing.Kemudian mencari alternatif pembiayaan yang paling baik dari keduanya, yaitu yang mempunyai biaya lebih kecil ditinjau dari present value aliran kas pembiayaan yang dihasilkan, sehingga diperoleh alternatif pembiayaan yang paling menguntungkan.

\section{Perumusan Hipotesis}

Diduga bahwa alternatif pembiayaan yang paling menguntungkan bagi UD.Riky S.Y dalam pengambilan keputusan penyediaan aktiva tetapnya adalah melalui alternatif pembiayaan leasing dibandingkan dengan alternatif pembiayaan debt financing

\section{METODE PENELITIAN}

Penelitian ini adalah penelitian terapan (applied research). "Penelitian terapan adalah penelitian yang mempunyai alasan praktis, keinginan untuk mengetahui dengan tujuan agar dapat melakukan sesuatu yang jauh lebih baik, lebih efektif dan efisien" (Siregar, 2013:4).Penelitian ini ingin membandingkan dua alternatif pembiayaan dalam pengambilan keputusan untuk penyediaan aktiva tetap bagi UD. Riky S.Y yaitu dengan menggunakan alternatif pembiayaan leasing dan alternatif pembiayaan debt financing, sehingga diperoleh alternatif pembiayaan yang dapat memberikan keuntungan bagi perusahaan jika ditinjau dari present value aliran kas pembiayaan yang dihasilkan yaitu yang mempunyai biaya yang lebih kecil atau dengan kata lain, jauh lebih efektif dan efisien.Metode pengumpulan data yang digunakan dalam penelitian ini adalah metode kasus atau sering disebut studi kasus (case study). Menurut Maxfield (1930) dalam Nazir (2011:57) menyatakan bahwa "studi kasus (case study) adalah penelitian tentang status subjek penelitian yang berkenan dengan suatu fase spesifik atau khas dari keseluruhan personalitas".Dalam penelitian ini penulis menggunakan studi kasus karena penelitian ini bertujuan untuk meneliti atau menelaah tentang kasus atau kejadian tertentu yang dihadapi oleh Perusahaan UD. Riky S.Y dalam pengambilan keputusan untuk memperoleh aktiva tetap yang akan digunakan.Adapun teknik pengumpulan data yang digunakan dalam penelitian ini adalah observasi, wawancara, dan dokumentasi yaitu suatu teknik pengumpulan data dari bukti-bukti tertulis, seperti biaya sewa dan biaya operasional.Alat pengumpulan data yang digunakan dalam penelitian ini adalah kuesioner dan tape recorder.Jenis data yang digunakan dalam penelitian ini adalah data kuantitatif dan data kualitatif.Adapun sumber data yang dipergunakan dalam penelitian ini adalah data primer dan data sekunder.Variabel-variabel yang terkait dalam penelitian ini dapat diidentifikasikan sebagai berikut :

1. Variabel biaya dengan adanya leasing :
a. Biaya sewa
b. Biaya operasional
c. Perlindungan pajak

2. Variabel biaya dengan adanya debt financing :
a. Biaya bunga
b. Biaya operasional
c. Biaya penyusutan
d. Perlindungan pajak

Metode analisis Present Valuedigunakan untuk menghitung aliran kas keluar.Cara ini digunakan untuk menentukan arus kas keluar yang mempunyai Present Value atau aliran kas yang lebih sedikit sehingga menguntungkan dalam analisis penentuan alternatif.Present Value di sini digunakan sebagai suatu standar terhadap alternatif yang ada untuk membandingkan dengan memakai dasar yang sama.

\section{HASIL DAN PEMBAHASAN}

UD.Riky S.Y merupakan perusahaan yang bergerak di bidang usaha budidaya perikanan air tawar dengan produk utamanya adalah ikan nila, berdiri tahun 2005. Modal yang digunakan oleh perusahaan ini 
terdiri atas modal sendiri dan modal pinjaman yang diperoleh dari kredit Bank Rakyat Indonesia (BRI) Cabang Mataram. UD.Riky S.Y beralamat di Jalan Baru Mekar Dusun Keroya Desa Gontoran Kecamatan Lingsar Kabupaten Lombok Barat. Setiap 5 (lima) tahun sekali perusahaan ini memperpanjang Surat Izin Usaha Perdagangan (SIUP) maka pada tahun 2010 perusahaan kembali memperpanjang atau memperbaharuinya dengan memperoleh nomor SIUP yang baru yaitu 503.B3/0499/BP2T-LB/2010 yang ditetapkan pada tanggal 19 November 2010. Selanjutnya perusahaan ini ditetapkan sebagai obyek pajak dengan Nomor Pokok Wajib Pajak (NPWP) yaitu 08.417.857.3-911.000 atas nama sendiri Bapak H. Lalu Najamudin selaku pemilik dan pimpinan perusahaan. Seluruh persyaratan administrasi ini juga dilengkapi dengan nomor TDP (Tanda Daftar Perusahaan Perseorangan) yaitu 230455206463.Sistem pembukuan yang digunakan oleh perusahaan ini sudah terstandar sesuai dengan sistem pembukuan yang telah ditetapkan oleh Direktorat Jenderal Pajak.

Dalam penelitian ini penyusutan dihitung dengan menggunakan metode persentase dari nilai buku. Untuk penyusutan Kolam Pemeliharaan Ikan dengan Ukuran 16 × 6 meter, perusahaan menetapkan tarif penyusutan sebesar $10 \%$ per tahun. Karena besarnya penyusutan untuk kendaraan operasional ditentukan oleh Pemerintah, yaitu melalui ketentuan yang terdapat dalam Peraturan Menteri Keuangan Nomor : 96/PMK.03/2009, yang menetapkan bahwa untuk semua jenis usaha dengan jenis aktiva : mobil, bus, truk, speed boat, dan sejenisnya termasuk ke dalam Kelompok 2 dengan masa manfaat 8 tahun dan besarnya tarif penyusutan adalah $25 \%$ per tahun.

Besarnya dana pinjaman adalah sebesar harga perolehan aktiva tetap yang di-lease dan dengan lama periode yang sama dengan lamanya periode lease. Harga perolehan satu unit kolam pemeliharaan ikan dengan ukuran 16 x 6 meter adalah sebesar Rp 40.000.000,- dan harga perolehan satu unit kendaraan (mobil pick up) adalah sebesar Rp 190.000.000,-. Tingkat bunga pinjaman yang digunakan adalah 13\% dan lamanya periode pinjaman adalah 5 tahun untuk kedua aktiva tetap tersebut.

Dalam penelitian ini, karena UD.Riky S.Y adalah UMKM yang berbentuk badan usaha yaitu perusahaan perseorangan maka dikenakan tarif pajak penghasilan sebesar 25\%.Penentuan tarif pajak penghasilan ini diperoleh atau diakses dari situs http:www.pajak.go.id pada hari Senin tanggal 18 November 2013 pukul 11.40 Wita.

Besarnya aliran kas keluar untuk alternatif leasing diperoleh dari pembayaran sewa ditambah biaya operasional dikurangi perlindungan pajak, dalam hal ini perlindungan pajak diperoleh dari pembayaran sewa ditambah biaya operasional dikalikan dengan tarif pajak yang berlaku yaitu 25\%.Sedangkan untuk alternatif debt financing, besarnya aliran kas keluar diperoleh dari pembayaran angsuran pinjaman ditambah biaya operasional dikurangi perlindungan pajak, dalam hal ini perlindungan pajak diperoleh dari biaya operasional ditambah bunga ditambah biaya penyusutan dikalikan dengan tarif pajak yang berlaku yaitu $25 \%$.

Aliran kas masuk dihitung dari nilai residu atau terminal cashflow pada akhir periode penyusutan dari aktiva tetap yang akan dibiayai dari alternatif debt financing. Terminal cashflow merupakan aliran kas yang diterima sebagai akibat habisnya umur ekonomis suatu aktiva tetap.Apabila aktiva tetap habis umur ekonomisnya biasanya masih ada penerimaan kas.Oleh karena itu yang termasuk dalam kelompok terminal cashflow adalah nilai residu.Terminal cashflow ini akan diterima pada akhir umur ekonomis, sehingga nantinya akan diperhitungkan sebagai cashflow di tahun terakhir.

Selama aktiva tetap dioperasikan, selama itu pula akan terjadi arus kas keluar (cash outflow), misalnya untuk membayar biaya-biaya operasional. Di sisi lain juga terjadi arus kas masuk (cash inflow), misalnya dari nilai residu. Bila arus kas masuk melebihi arus kas keluar, maka akan terdapat arus kas masuk bersih (net cash inflow), sebaliknya bila arus kas masuk lebih kecil daripada arus kas keluar, maka akan terdapat arus kas keluar bersih (net cash outflow).

Setelah aliran kas masing-masing alternatif diketahui, maka untuk selanjutnya aliran kas keluar tersebut akan di-present value-kan dengan menggunakan discount factor yang sama besarnya untuk setiap alternatif. Tingkat diskonto yang tepat untuk mendiskontokan aliran kas keluar adalah tingkat bunga pinjaman setelah pajak. Dalam penelitian ini tingkat bunga pinjaman setelah pajak adalah sebesar :

$$
\begin{aligned}
& \text { Discount Factor }=\text { tingkat bunga pinjaman }(1-\text { tarif pajak }) \\
&=13 \%(1-25 \%) \\
&=9,75 \%
\end{aligned}
$$

Dengan tingkat bunga inilah kedua alternatif tersebut akan di-present value-kan. Alternatif yang akan dipilih adalah alternatif yang memberikan pengorbanan biaya yang lebih kecil, yaitu yang memiliki present value aliran kas keluar yang lebih kecil atau net cash outflow yang jauh lebih kecil. 
Tabel 3.Perbandingan Kriteria Biaya antara Alternatif Leasing dan Alternatif Debt Financing Aktiva Tetap Kolam Pemeliharaan Ikan dengan Ukuran 16 x 6 meter dan Kendaraan (Mobil Pick Up) periode 2013/2014-2017/2018.

\begin{tabular}{|c|c|c|}
\hline \multirow{2}{*}{$\begin{array}{c}\text { Alternatif } \\
\text { Pembiayaan }\end{array}$} & \multicolumn{2}{|c|}{ Aktiva Tetap } \\
\hline & Kolam & Mobil Pick Up \\
\hline Leasing & $\operatorname{Rp} 48.278 .250$ & Rp 398.823.300 \\
\hline Debt Financing & $\mathrm{Rp} 66.530 .066$ & $\mathrm{Rp} 222.446 .799$ \\
\hline Kriteria Biaya & $\begin{array}{l}\text { Lebih kecil dengan alternatif } \\
\text { leasing }\end{array}$ & $\begin{array}{l}\text { Lebih kecil dengan alternatif } \\
\text { debt financing }\end{array}$ \\
\hline Keputusan & Leasing & Debt Financing \\
\hline
\end{tabular}

Dari Tabel 3 di atas dapat dilihat bahwa total present value aliran kas keluar aktiva tetap kolam pemeliharaan ikan dengan ukuran 16 x 6 meter periode 2013/2014-2017/2018 untuk alternatif leasing adalah sebesar Rp 48.278.250,-. Sedangkan untuk alternatif debt financing pada periode yang sama jika dilihat dari total aliran kas bersih yang dikeluarkan (net cash outflow) adalah sebesar Rp 66.530.066,-. Besarnya total present value aliran kas keluar aktiva tetap kendaraan (mobil pick up) periode 2013/2014-2017/2018 untuk alternatif leasing adalah sebesar Rp 398.823.300,-. Sedangkan untuk alternatif debt financing pada periode yang sama jika dilihat dari total aliran kas bersih yang dikeluarkan (net cash outflow) adalah sebesar Rp 222.446.799,-. Dengan demikian, berdasarkan kriteria biaya dalam hal ini total present value aliran kas keluar pada alternatif leasing dan total aliran kas bersih yang dikeluarkan (net cash outflow) pada alternatif debt financing maka diperoleh keputusan yaitu UD. Riky S.Y di dalam mengambil keputusan tentang penyediaan aktiva tetap berupa satu unit kolam pemeliharaan ikan dengan ukuran 16 x 6 meter lebih baik diperoleh dengan alternatif pembiayaan leasing, sedangkan untuk satu unit kendaraan (mobil pick up) lebih baik diperoleh dengan alternatif pembiayaan debt financing.

Dari hasil analisis data yang telah dilakukan, maka dapat dikemukakan bahwa besarnya total present value aliran kas keluar untuk aktiva tetap kolam pemeliharaan ikan dengan ukuran 16 x 6 meter dengan alternatif leasing periode 2013/2014-2017/2018 adalah sebesar Rp 48.278.250,-. Sedangkan untuk alternatif debt financing pada periode yang sama jika dilihat dari total aliran kas bersih yang dikeluarkan (net cash outflow) adalah sebesar Rp 66.530.066,-- Besarnya total present value aliran kas keluar untuk aktiva tetap kendaraan (mobil pick up) dengan alternatif leasing periode 2013/2014-2017/2018 adalah sebesar Rp 398.823.300,- dan untuk alternatif debt financing pada periode yang sama jika dilihat dari total aliran kas bersih yang dikeluarkan (net cash outflow) adalah sebesar Rp 222.446.799,--

Dari hasil analisis perhitungan present value aliran kas keluar dan aliran kas bersih yang dikeluarkan (net cash outflow) tersebut terlihat bahwa besarnya total present value aliran kas keluar pada alternatif leasing untuk aktiva tetap kolam pemeliharaan ikan dengan ukuran 16 x 6 meter adalah lebih kecil jika dibandingkan dengan total aliran kas bersih yang dikeluarkan (net cash outflow) pada alternatif debt financing. Namun, sebaliknya besarnya total present value aliran kas keluar pada alternatif leasing untuk aktiva tetap kendaraan (mobil pick up) adalah lebih besar jika dibandingkan dengan total aliran kas bersih yang dikeluarkan (net cash outflow) pada alternatif debt financing. Hal tersebut menunjukkan bahwa pemenuhan kebutuhan aktiva tetap dengan alternatif leasing untuk kolam pemeliharaan ikan dengan ukuran 16 x 6 meter memberikan pengorbanan biaya yang lebih sedikit atau lebih kecil daripada biaya-biaya yang dikeluarkan pada alternatif debt financing. Sedangkan pemenuhan kebutuhan aktiva tetap dengan alternatif debt financing untuk kendaraan (mobil pick up) memberikan pengorbanan biaya yang lebih sedikit atau lebih kecil daripada biaya-biaya yang dikeluarkan pada alternatif leasing.

Dengan demikian dari penelitian ini diperoleh perbandingan dalam pengambilan keputusan di mana UD. Riky S.Y di dalam mengambil keputusan tentang penyediaan aktiva tetap berupa satu unit kolam pemeliharaan ikan dengan ukuran 16 × 6 meter lebih baik diperoleh dengan alternatif pembiayaan leasing, sedangkan untuk satu unit kendaraan (mobil pick up) lebih baik diperoleh dengan alternatif pembiayaan debt financing.

\section{SIMPULAN}

Hasil penelitian menunjukkan sebagai berikut :

1. Besarnya total present value aliran kas keluar untuk aktiva tetap kolam pemeliharaan ikan dengan ukuran 16 x 6 meter dengan alternatif leasing periode 2013/2014-2017/2018 adalah sebesar Rp 48.278.250,-. Sedangkan untuk alternatif debt financing pada periode yang sama jika dilihat dari total aliran kas bersih yang dikeluarkan (net cash outflow) adalah sebesar Rp 66.530.066,-. Besarnya total present value aliran 
kas keluar untuk aktiva tetap kendaraan (mobil pick up) dengan alternatif leasing periode 2013/20142017/2018 adalah sebesar Rp 398.823.300,- dan untuk alternatif debt financing pada periode yang sama jika dilihat dari total aliran kas bersih yang dikeluarkan (net cash outflow) adalah sebesar Rp 222.446.799,-.

2. Pemenuhan kebutuhan aktiva tetap dengan alternatif leasing untuk kolam pemeliharaan ikan dengan ukuran 16 x 6 meter memberikan pengorbanan biaya yang lebih sedikit atau lebih kecil daripada biayabiaya yang dikeluarkan pada alternatif debt financing. Sedangkan pemenuhan kebutuhan aktiva tetap dengan alternatif debt financing untuk kendaraan (mobil pick up) memberikan pengorbanan biaya yang lebih sedikit atau lebih kecil daripada biaya-biaya yang dikeluarkan pada alternatif leasing. Dengan demikian UD. Riky S.Y di dalam mengambil keputusan tentang penyediaan aktiva tetap berupa satu unit kolam pemeliharaan ikan dengan ukuran 16 x 6 meter lebih baik diperoleh dengan alternatif pembiayaan leasing, sedangkan untuk satu unit kendaraan (mobil pick up) lebih baik diperoleh dengan alternatif pembiayaan debt financing.

\section{DAFTAR PUSTAKA}

Ariningsih, Catur. 1998. Analisis Leasing dan Debt Financing Peralatan pada PT. Jaya Konstruksi Perwakilan NTB. Fakultas Ekonomi Universitas Mataram : Skripsi yang tidak dipublikasikan.

Dyaswati, Ninik. 1990. Analisis Leasing dan Debt Financing Peralatan pada PT. Nindya Karya Perwakilan Nusa Tenggara Barat. Fakultas Ekonomi Universitas Mataram : Skripsi yang tidak dipublikasikan.

Hadibroto. 2006. Dasar-dasar Akuntansi. LP3ES : Jakarta.

Hanafi, Mamduh M. 2004. Manajemen Keuangan. Edisi 2004/2005. BPFE Yogyakarta : Yogyakarta. http://komite-kur.com/bank_bri.asp diakses pada hari Jumat tanggal 11 Oktober 2013 pukul 12.58 Wita.

http:www.pajak.go.id/sites/default/files/HKWP-Bab2_o.pdf diakses pada hari Senin tanggal 18 November 2013 pukul 11.40 Wita.

Jusup, Al. Haryono. 2003. Dasar-dasar Akuntansi. Jilid 1.Edisi ke-6. Sekolah Tinggi Ilmu Ekonomi YKPN : Yogyakarta.

YKPN : Yogyakarta.

Kartadinata, Abas. 1983. Pembelanjaan (Pengantar Manajemen Keuangan). PT. Bina Aksara : Jakarta.

Kurniasih, Yunita. 2001. Analisis Leasing dan Debt Financing Peralatan pada PT. Muara Ema di Kodya Mataram. Fakultas Ekonomi Universitas Mataram : Skripsi yang tidak dipublikasikan.

Nazir, Moh. 2011. Metode Penelitian. Cetakan Ketujuh. Ghalia Indonesia : Bogor.

Siregar, Syofian. 2013. Metode Penelitian Kuantitatif : Dilengkapi dengan Perbandingan Perhitungan Manual dan SPSS. Edisi Pertama. Kencana Predana Media Group : Jakarta.

Sutrisno. 2003. Manajemen Keuangan : Teori, Konsep, dan Aplikasi. Ekonisia : Yogyakarta. 